\title{
Asssessment of some selected vitamin levels in patients with vesico - vaginal fistula in Jos, Northern Nigeria.
}

\author{
Evaluación de niveles de vitamina seleccionados en pacientes con fístula \\ vesico - vaginal en Jos, norte de Nigeria. \\ Sunday-Adeoye, Ileogben'1., Uraku, Anayo. Joseph²., Uraku, Oluchi Helen²., \\ Lengmang, Sunday Joseph ${ }^{3}$. \& Chima, Godwin Amadi. ${ }^{3}$
} Sunday-Adeoye, I., Uraku, A.J., Uraku, O.H., Lengmang, S.J. \& Chima, G.A. Asssessment of some selected
vitamin levels in patients with vesico - vaginal fistula in jos, Northern Nigeria. Int. J. Med. Surg. Sci., 4(3):1209-1215., 2017.

SUMMARY: Globally, about 3.5 million women are living with genitourinary fistula, a miserable condition. Obstetric Vesicovaginal fistula (VVF) is exceptionally rare in developed part of the world, where it is mostly due to gynaecological cause. The study was conducted to provide baseline data on vitamin A and vitamin E levels among Vesico - Vaginal Fistula (VVF) patients and to establish their socio-demographic characteristics. Some selected vitamin levels in patients with Vesico - Vaginal Fistula (VVF) in Jos, Northern Nigeria were investigated using spectrophotometric method. Samples were collected from VVF patients undergoing treatments at the Evangel Hospital, Jos and the controls were non pregnant but parous women of similar social status who were willing to participate in the study. A total of 97 participants made up of $67 \mathrm{VVF}$ patients and 30 controls were involved in the study. The results revealed that only 1 clients (1.49\%) was mulliparous, $50(74.64 \%)$ and $16(23.88 \%)$ clients were multiparous and grand multiparous respectively out of $67(100 \%)$ clients. The results of social class distribution in both clients and control is in the order of $5>4>3,2>1$. The levels of vitamin $A$ in VVF clients showed no significant change $(p>0.05)$ when compared to control while that of vitamin $\mathrm{E}$ showed significant change $(p<0.05)$. The results of viatamin A and $E$ in respect to age, social class and parity showed significant difference $(p<0.05)$ in the VVF patients than the control except for those with age $25-29$ and $40-44$ years as well as social class 1 and 5 . The study therefore highlights need for determination of reference values of vitamins levels among African population.

KEYWORDS: genitourinary fistula, gynaecological, pregnancy, maternal mortality, children, malnutrition, micronutients, Northern Nigeria.

\section{INTRODUCCIÓN}

Pregnancy related death is a worrisome problem particularly in the developing countries of the world like Nigeria. Though, maternal death appears to be under reported in most developing countries, but the rates reported for Nigeria is still unacceptably high (Babayemi \& Olorunpomi, 2012). Maternal mortality is an enormous subject that has been comprehensively studied.

The cause of maternal death most often has its roots in a woman's life before pregnancy, during infancy or even before her birth when deficiencies of calcium, vitamin D, or iron begin (Baba, 2014). Malnutrition may result in chronic iron deficiency anemia and death from hemorrhage, and referred to maternal depletion from pregnancies spaced too closely together. Deaths during pregnancies do not usually result from malnutrition alone, but from conditions that may be exacerbated by poor nutrition (Rush, 2000).

The primary causes of maternal mortality in Nigeria include hemorrhage, obstructed labor, pregnancy-induced hypertension, puerperal infection and induced abortion among others (Baba). Often, some mothers who survive the ordeal of prolonged obstructed labour end up with soft tissue morbidities like obstetric fistula, foot drop (Lawson, 1976; Baba).

Maternal morbidities like obstetric fistulas constitute a social disaster of enormous proportion associated with loss of their dignity as women and as a human being with progressive downgrading medically, socially and mentally and become outcast in their community (Ekwempu, 1988; Lawson, 1992; Danso, 2005). The Obstetric fistula is a major public health/social problem on the increase in Nigeria which fortunately has only recently started to receive global attention from UNFPA, FIGO, WHO

\footnotetext{
1. South - East Fistula Centre, Abakaliki, Ebonyi State.

3. Department of Biochemistry, Ebonyi State University, Abakaliki, Ebonyi State Nigeria.

3. Evangel Hospital, Jos.
} 
Sunday-Adeoye, I., Uraku, A.J., Uraku, O.H., Lengmang, S.J. \& Chima, G.A. Asssessment of some selected vitamin levels in patients with vesico - vaginal fistula in Jos, Northern Nigeria. Int. J. Med. Surg. Sci., 4(3):1209-1215., 2017.

(Babayemi \& Olorunpomi).

Vesico-Vaginal Fistula (VVF) is an abnormal communication between the vaginal and the urinary bladder resulting in continuous and involuntarily leakage of urine per vaginam (Umoiyoho, et al. 2011). In the developing countries like Nigeria, acquired fistulas commonly results from prolonged obstructed labour. Prolonged impaction of the fetal presenting part on the pubis symphysis anteriorly, the sacrum posteriorly results in ischemic necrosis with subsequent sloughing of the devitalized tissue from the third day.

The result is urinary and fecal leakage from the $3^{\text {rd }}$ postpartum day (Umoiyoho, et al. 2011). Other aetiological factors of obstetric origin include instrumental deliveries, destructive operations and Caesarean sections. It could also be iatrogenic, where it may complicate major gynaecological surgeries like vaginal and abdominal hysterectomies (Lawson, 1992). It may also complicate advanced cervical malignancies with erosion of the tumour into the bladder. Radiotherapy as a treatment procedure for cancer of the cervix may be complicated by VVF. Vesico - Vaginal Fistula following irradiation is the commonest type of VVF seen in the developed world (Peel, 1994).

In Northern Nigeria, there is the variety of VVF that often follows the Yankan gishiri, which is a cut on the anterior vaginal wall given by the local barber as a remedy for most Obstetric and gynaecological disorders. Though, there are no precise figures on the prevalence of this condition in Nigeria, the country has been reported to have the highest number of VVF cases worldwide (Okoye, et al. 2014).

About 1.5 million cases of VVF exist in Africa and 250,000 in Nigeria alone(Waaldijk, 2003). To tackle this menace, several VVF centers' have been established in Nigeria and these include the South East Fistula Centre in Abakaliki, Ebonyi State, family life centre in Uyo, Akwa Ibom, State, in Southern Nigeria. In Northern Nigeria the VVF centres exist in Jigawa, Kano, Kaduna, Katsina, Kebbi, Sokoto and Plateau States. The scourge was previously thought to be a problem of Northern Nigeria alone but emerging experience shows it is likely to be a national scourge.

Because of the constant smell of urine, many of the women are reportedly driven from their homes by their husbands and in-laws. They are also unacceptable to their fellow women for the same reason and so cannot partake in daily communal activities (Karshinia, 2006). In some communities in Ebonyi state, many women believe it is an affliction of the gods to these women for infidelity. These factors make them a vulnerable group of the society.

The two most important predisposing factors to fistula formation are poverty and ignorance in a large proportion of patients. Because of poor nutrition, these women fail to achieve their true growth potential and are often of short stature and thus have reduced pelvic capacities which may eventually predispose them to prolonged and difficult labour (Odu \& Cleland, 2013).

Obstructed labor is also strongly related to a woman's age and parity (Ngoma, 2010). Very young women and women giving birth for the first time are at much higher risk of obstructed labour, although it is far more likely that obstructed labor will lead to a ruptured uterus in the multiparae.

Kelly and Kwast (1993), reported that $63 \%$ of women with a fistula experienced it after their first labour. Lack of financial capacity also hindered these patients from assessing health care early in the labour process, setting the stage for prolonged labour and fistula formation. The basic role of host nutrition in disease conditions has however remained a significant lacuna in scientific knowledge.

Though, there appears to be conflicting reports about the place of nutritional supplement in the maintenance of optimal health, prevention of disease, increasing the life span and reducing maternal mortality (Ngoma, 2010). Some recent evidences presently suggest that those individuals who consume nutritional supplements may have a lower risk of cardiovascular diseases, cancer, osteoporosis and reduction of maternal mortality (Codex, 2000; Rush, 2000). Vitamins are organic compounds and are vital nutrients required by human in limited amounts (Okaka, et al. 2006).

They play essential roles in enzymes and hormones synthesis including other substances, helping to regulate growth, activity, development and the functioning of the immune and reproductive systems (Uraku, 2015). Adequate intake is very crucial during early childhood, pregnancy and breastfeeding and for rapid growth etc (Okaka, et al. 2006).

Lack of these essential nutrients may affect the development which can result in short stature and ultimately prolonged obstructed labour and VVF. In view of the role of nutrition in the reduction of maternal mortality and morbidity, this study seeks to assess the vitamin $A$ and $E$ levels among VVF patients of various social classes in Jos, Northern Nigeria.

\section{METHODOLOGY}

\section{Study area and population:}

This study was conducted using patients with Vesico-Vaginal Fistula in Evangel Hospital, Jos. The hospital is one of the Centres for VVF surgery in Northern Nigeria. The study was a total population study involving all the patients in the centre between January to March 2006 who consented to be part of the study. The controls were non-pregnant but parous women of similar social status who were willing to participate in the study. 
Sunday-Adeoye, I., Uraku, A.J., Uraku, O.H., Lengmang, S.J. \& Chima, G.A. Asssessment of some selected vitamin levels in patients with vesico - vaginal fistula in Jos, Northern Nigeria. Int. J. Med. Surg. Sci., 4(3):1209-1215., 2017.

\section{Ethical approval:}

Ethical approval was obtained from the Ethical Committee of Ebonyi State University Teaching Hospital, Abakaliki and an informed consent was also obtained from all the participants in the study. Those who failed to give their consent were excluded from the study. Demograghic characteristics, like age at marriage, height and social class etc were also obtained from the participants.

\section{Sample collection and preparation:}

About $10 \mathrm{ml}$ of blood was collected from each participant, using a syringe and transferred into a sample bottle without an anticoagulant. The blood samples were transferred into centrifuging tubes and were centrifuged at 3000rpm for 15 minutes.

The serum was collected, and the clotted blood residue was discarded. The serum samples were left frozen at $-200^{\circ} \mathrm{C}$ until needed and then refrigerated using a cold chain. The collected serum was then sent to the laboratory for vitamin $A$ and $E$ analysis using spectrophotometric method.

\section{Determination of vitamins:}

The blood was centrifuged at 3000rpm per minute for 15 minutes. About $5 \mathrm{ml}$ of acetone was added to $0.5 \mathrm{ml}$ of serum and then shaken properly. About $2 \mathrm{ml}$ of distilled water and $5 \mathrm{ml}$ of petroleum ether was then added. The mixture was also shaken properly. There was a separation of the oily layer on top of the non-oily liquid.

The top layer was gently collected with a pipette and transferred into the curvette and the absorbance was read at a wave length of $423 \mathrm{~nm}$ and $450 \mathrm{~nm}$ respectively, for vitamin A and E using 722 Spectrophotometer

\section{Statistical analysis:}

The data was analyzed by ANOVA and results expressed as means \pm standard deviation and percentage.

\section{RESULTS}

The mean age for the patients was 28.83 years \pm 10.37 with a range of $18-80$ years (Table 1 ). Majority of the patients (40\%) were less than 25years and the mean age for the control was $33.23 \pm 9.22$. Only one patient $(1.49 \%)$ was nulliparous. While 50 patients (74.63\%) were primiparous (multiparaous) and 16 patients $(23.88 \%)$ were grandimultiparous. The mean parity for the patients was $2.90 \pm 2.65$, (Table 1), while the mean parity for the control was $3.93 \pm 2.09$.

The average height of the VVF patients was $144.5 \mathrm{~cm}$ and majority (71.6\%) of the VVF patients were below the critical height of $153 \mathrm{~cm}$. The average height for the control was $163.5 \mathrm{~cm}$ and all of them were above the critical height of $153 \mathrm{~cm}$. The average age at marriage for the patients were 15.9 years while $86.4 \%$ of the patients married before the age of 20 years. The average age of marriage for the control was 23.3 years while only $13.0 \%$ of the controls were married before the age of 20 years.

All the 66 parous patients lost their fetuses in the index pregnancy and had not conceived again and the complication followed obstructed labour in 66 patients except in one patient who developed VVF following a gynaecological procedure.

Table. 1. Summary of Age and Parity Distribution of the VVF patients

\begin{tabular}{|lcccrr|}
\hline & $\begin{array}{c}\text { Para zero } \\
\text { (Nullips) }\end{array}$ & $\begin{array}{c}\text { PARITY } \\
\text { Para 1-4 } \\
\text { (Multips) }\end{array}$ & $\begin{array}{c}\text { Para 5-11 } \\
\text { (Grand multips) }\end{array}$ & Total \\
\hline AGE: & $\leq 19$ yrs & 0 & 7 & 0 & $7(10.45 \%)$ \\
& $20-34$ yrs & 1 & 32 & 10 & $43(64.18 \%)$ \\
& $\geq 35$ yrs & 0 & 11 & 6 & $17(25.37 \%)$ \\
TOTAL & $1(1.49 \%)$ & $50(74.63 \%)$ & $16(23.88 \%)$ & $67(100 \%)$ \\
\hline
\end{tabular}

$\mathrm{X}^{2}=3.993 ; \mathrm{df}=4 ; p=0.407$

Table. 2. Social Class distribution of the fistula patients and control.

\begin{tabular}{|ccc|}
\hline Social class & Patients (\%) & Control (\%) \\
\hline 1 & 0 & $1(3.33)$ \\
2 & $1(1.49)$ & $1(3.33)$ \\
3 & $1(1.49)$ & $1(3.33)$ \\
4 & $4(5.97)$ & $2(6.67)$ \\
5 & $61(91.05)$ & $25(83.33)$ \\
Total & $67(100)$ & $30(100)$ \\
\hline
\end{tabular}

$\mathrm{X}^{2}=3.07 ; \mathrm{df}=4 ; p=0.546$ 
FIGURE. 1. Values of vitamin A and $E$ for the patients and control.

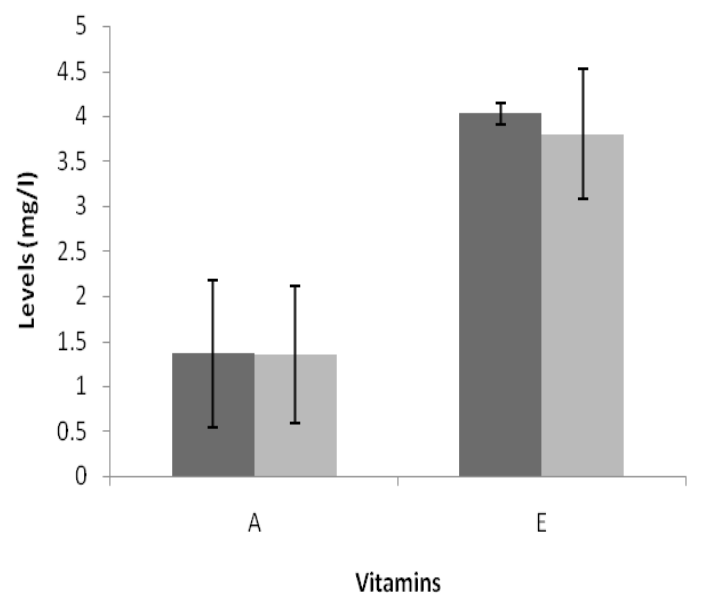

-VVF

Control

The results showed that there were no significant difference $(p>0.05)$ in the levels of vitamin A in the VVF patients when compared to control while that of vitamin $\mathrm{E}$ showed a significant elevation $(p<0.05)$ in the VVF patients when compared with the control.

FIGURE. 2b. Mean serum levels of vitamin A (mg/l) in VVF Patients and control vis-a-vis Social class.

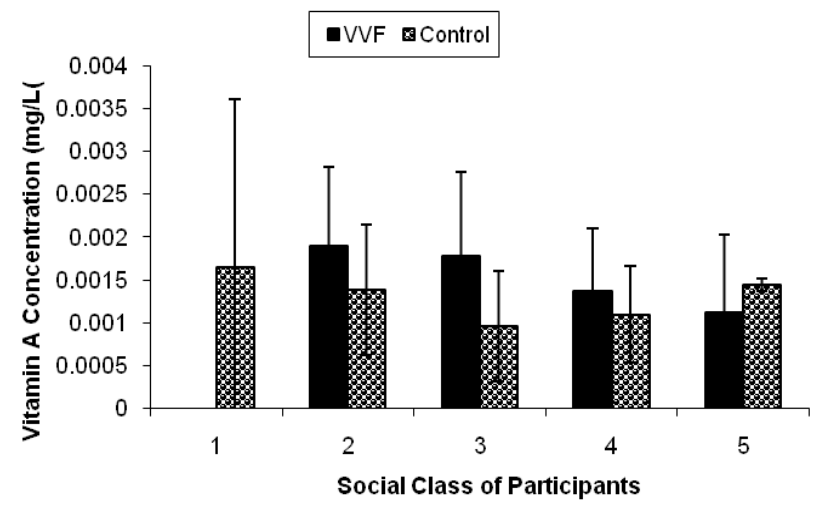

The results showed that there were significant increase $(p<0.05)$ in the levels of vitamin A in respect to social class in the VVF patients when compared to control at class 2, 3 and 4 with a significant reduction $(p<0.05)$ in VVF patients at only social class 5 when compaed to control.
FIGURE. 2a. Mean serum levels of vitamin A $(\mathrm{mg} / \mathrm{l})$ in VVF patients and control vis-a-vis Age.

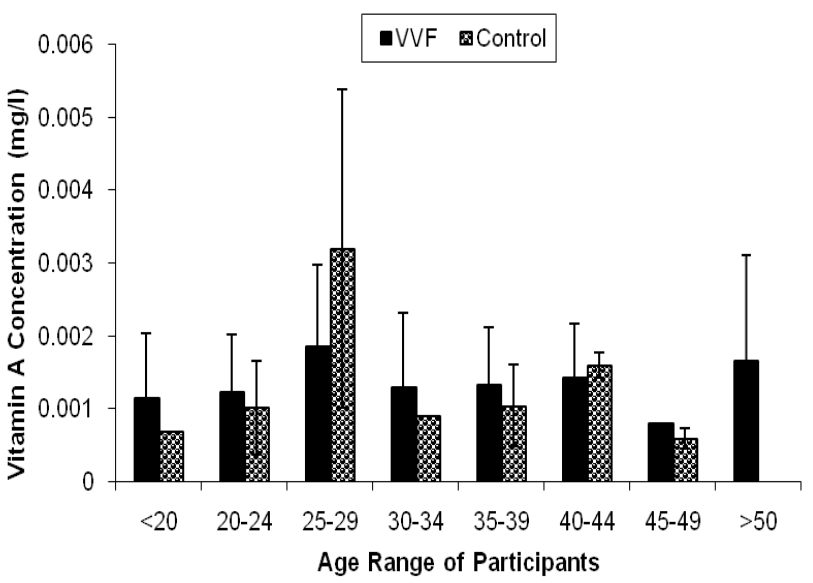

The results showed that there was significant increase $(p<0.05)$ in the levels of vitamin A in the VVF patients when compared to control at age ranges of $<20,20-24,30-34,35-$ 39 and 45-49 with a significant reduction $(p<0.05)$ in VVF patients at age ranges of 25-29 and 40-44 when compaed to control.

FIGURE. 2C. Mean serum levels of vitamin A (mg/l) in VVF Patients and control vis-a-vis parity.

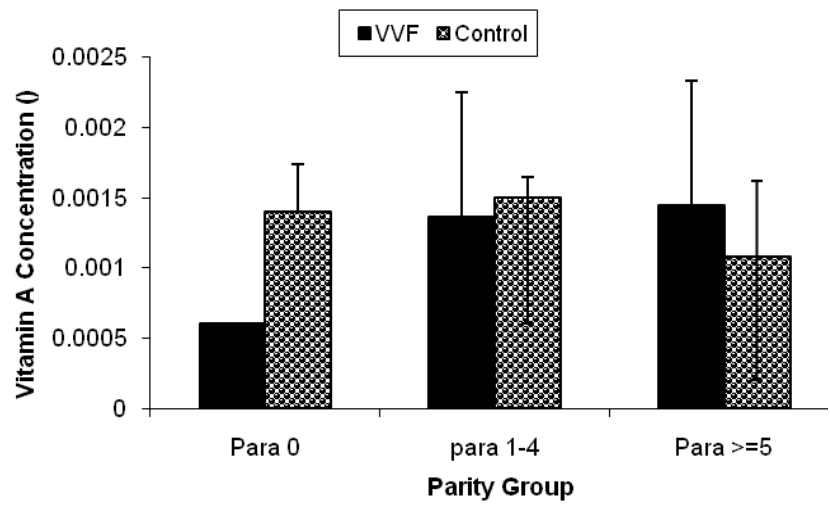

The result showed that there was significant increase $(p<0.05)$ in the levels of vitamin A in respect to parity in the VVF patients when compared to control at only para $>=5$ while at para 0 and para 1-4, there were significant reduction $(p<0.05)$ in VVF patients when compaed to control.

\section{DISCUSSION}

Out of 67 VVF patients assessed, patients with age range of 20-34 years had $43(64.18 \%)$ while those with age of $<19$ years had the list number $7(10.45 \%)$. Also, multiparous patients had the highest value of $50(74.45 \%)$ and were followed by grandmultiparous patients 16 (23.88\%). The observed high percentage of $74.45 \%$ in multiparous patients is aligned with report that multiparous are at much higher risk of obstructed labour which results to a ruptured uterus (Mehmood, et al. 2009; Ngoma, 2010). The reason for developing prolonged obstructed labour after four normal vaginal deliveries may be because of increasing fetal weight with successive pregnancies and increasing lumbar lordosis with successive pregnancies which may reduce the pelvic parameters especially the pelvic inlet (Odu \& Cleland, 2013).

The average height of the VVF patients was $144.5 \mathrm{~cm}$ and majority (71.6\%) of the VVF patients were below the critical height of $153 \mathrm{~cm}$ while that of the control was $163.5 \mathrm{~cm}$ and all of them were above the critical height of $153 \mathrm{~cm}$. These results are in order with the work of Thompson (1959), Akingba, (1971) Mallika, (1974) Kasongo (1987) who reported that maternal height is related to obstructed or prolonged 
Sunday-Adeoye, I., Uraku, A.J., Uraku, O.H., Lengmang, S.J. \& Chima, G.A. Asssessment of some selected vitamin levels in patients with vesico - vaginal fistula in Jos, Northern Nigeria. Int. J. Med. Surg. Sci., 4(3):1209-1215., 2017.

FIGURE. 3a. Mean serum levels of vitamin E $(\mathrm{mg} / \mathrm{l})$ in VVF Patients and control vis-a-vis Age.

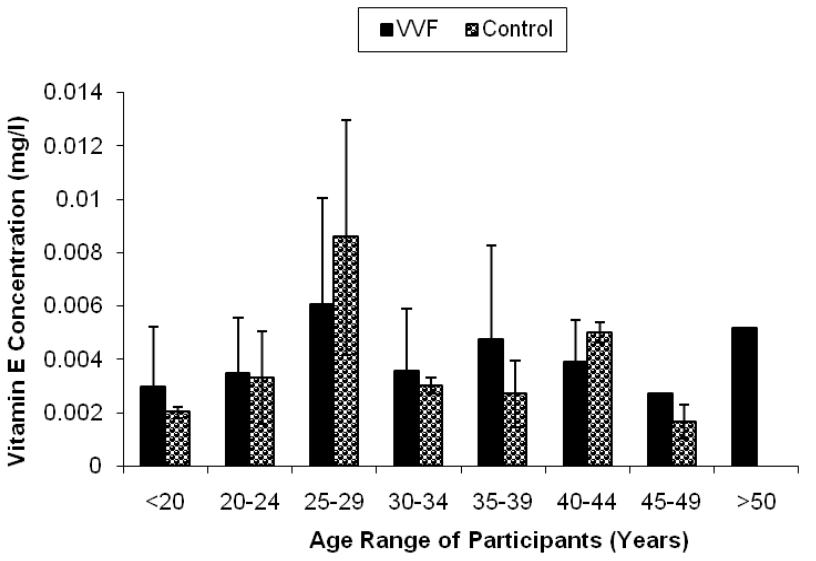

The results showed that there were significant increase $(p<0.05)$ in the levels of vitamin $\mathrm{E}$ in the VVF patients when compared to control at age ranges of $<20,30-34,35-39$ and $45-$ 49 but no significant change ( $p>0.05)$ at only age range of $20-24$ while at age ranges of 25-29 and 40-44, there were sginificant reduction at 25029 and 40-44 when compared to control.

FIGURE. 3c. Mean serum levels of vitamin E $(\mathrm{mg} / \mathrm{l})$ in VVF Patients and control vis-a-vis parity

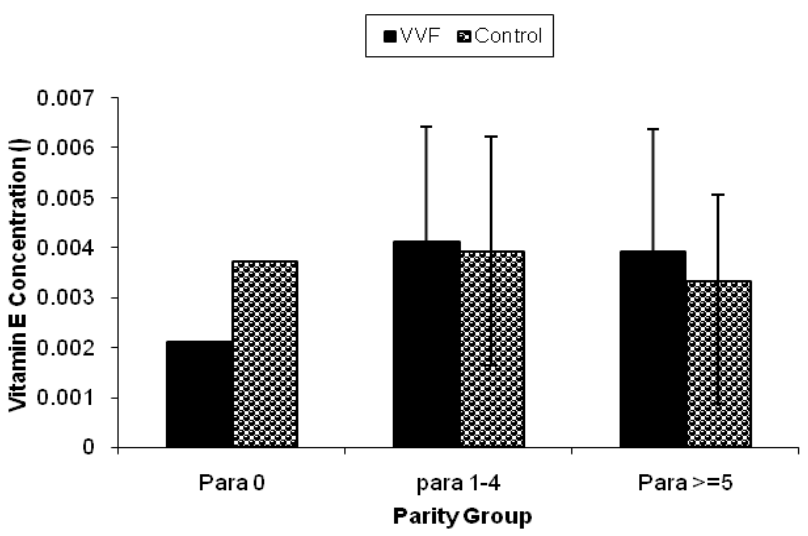

The result showed that there was significant increase $(p<0.05)$ in the levels of vitamin $\mathrm{E}$ in respect to parity in the VVF patients when compared to control at only para $>=5$ while at para 0 , there was significant reduction $(p<0.05)$ in VVF patients when compaed to control.

labour and is more prevalent in short women. The obtained result of lower percent of nulliparous disagrees with the report that clear majority of the VVF patients developed the complication in their first pregnancy (Baba).

Also, the average age at marriage for the patients were 15.9 years while $86.4 \%$ of the patients married before the age of 20 years with 23.3 years age of marriage for the control while only $13.0 \%$ of the controls were married before the age of 20 years. All the 66 parous patients lost their fetuses in the
FIGURE. 3b. Mean serum levels of vitamin E (mg/l) in VVF Patients and control vis-a-vis Social class.

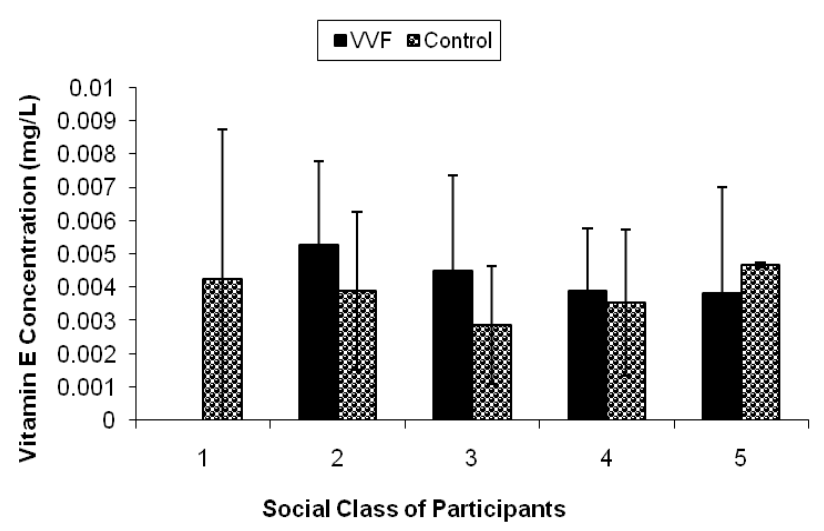

The result showed that there was significant increase $(p<0.05)$ in the levels of vitamin $E$ in respect to social class in the VVF patients when compared to control at 2, 3 and 4 while at 1 and 5 , there were significant reduction $(p<0.05)$ in VVF patients when compared to control.

index pregnancy and had not conceived again, and the complication followed obstructed labour in 66 patients except in one patient who developed VVF following a gynaecological procedure. However, there was no significant difference $(p>0.05)$ between the social classifications of the VVF patients when compared with the control as shown in table 2 .

The observed results agreed with the report of Mohamed et al.(2009) who stated that both short stature and marrying at a relatively young age predisposed woman to prolonged obstructed labour. Also, the unacceptably high fetal wastage observed in this study agreeed with the literature report that patients with Obstetric Fistula lost their babies in the index pregnancy (Aboh, et al. 2013). Thus, pointing to the fact that multiparous women can develop prolonged obstructed labour and develop obstetric fistula after several normal vaginal deliveries(Baba).

The results of vitamin analysis showed that there was no significant difference $(p>0.05)$ in the levels of vitamin $A$ in the VVF patients when compared to control while that of vitamin $E$ showed a significant elevation $(p<0.05)$ in the VVF patients when compared with the control. The obtained values of both vitamin $A$ and $E$ in this study are lower than reported analyate reference values for vitamin $A$ $(0.35-0.93 \mathrm{mg} / \mathrm{l})$ and vitamin E (5.17-18.09 $\mathrm{mg} / \mathrm{l})$ as reported by Carl, et al. 2006. The observation of low level of vitamin A and E among both groups is not surprising considering the similar social class of the population studied. This may be attributed to their lower socioeconomic class and are such may not be able to afford foods rich in these vitamins which generally are more expensive. 
The results of vitamin A levels in VVF Patients and Control vis-a-vis Age showed that there was significant increase $(p<0.05)$ in the levels of vitamin $A$ in the VVF patients when compared to control at variable age ranges of $<20,20-24,30-34,35-39$ and 45-49. Also, there was a significant reduction $(p<0.05)$ in VVF patients at age ranges of $25-29$ and 40-44 when compaed to control. Similarly, the results of Vitamin E in VVF Patients and Control vis$a-v i s$ Age indicated significant increase $(p<0.05)$ in the levels of vitamin $E$ in the VVF patients when compared to control at age ranges of $<20,30-34$, $35-39$ and $45-49$ but no significant change ( $p>0.05$ ) at only age range of 20-24 while at age ranges of 25-29 and 40-44, there were sginificant reduction at 25029 and 40-44 when compared to control.

In respect to Social class, there were significant increase $(p<0.05)$ in the levels of both vitamin $A$ and $E$ in respect to social class in the VVF patients when compared to control at class 2, 3 and 4 with a significant reduction $(p<0.05)$ in VVF patients at only social class 5 when compaed to control except at 1 and 5 of vitamin $E$ only, there were significant reduction $(p<0.05)$ in VVF patients when compared to control. Furthermore, there was significant increase $(p<0.05)$ in the levels of both vitamin $A$ with regards to parity in the VVF patients when compared to control at only para $>=5$ while at para 0 and para $1-4$, there were significant reduction $(p<0.05)$ in VVF patients when compaed to control. Also, there was significant increase $(p<0.05)$ in the levels of vitamin $E$ in respect to parity in the VVF patients when compared to control at only para $>=5$ while at para 0 , there was significant reduction $(p<0.05)$ in VVF patients when compaed to control.

In conclusion, sociodemographic variables have serious effect in high risk of prolonged obstructed labour but did not appear to have any effect on serum levels of vitamins in VVF patients.

Sunday-Adeoye, I., Uraku, A.J., Uraku, O.H., Lengmang, S.J. \& Chima, G.A. Evaluación de niveles de vitamina seleccionados en pacientes con fístula vesico - vaginal en Jos, norte de Nigeria. Int. J. Med. Surg. Sci., 4(3):1209-1215., 2017.

RESUMEN: A nivel mundial, alrededor de 3,5 millones de mujeres viven con fístula genitourinaria. La fístula vesicovaginal (FVV) obstétrica es excepcionalmente rara en el mundo desarrollado, donde se debe principalmente a causas ginecológica. Este estudio se realizó para proporcionar datos de referencia sobre los niveles de vitamina A y vitamina E entre los pacientes con FVV y para establecer sus características sociodemográficas. Los niveles de vitamina A y E en pacientes con VVF en Jos, norte de Nigeria se investigaron mediante el método espectrofotométrico. Se recogieron muestras de pacientes con FVV que se sometieron a tratamientos en el Evangel Hospital, Jos y un grupo control de paciente, no embarazadas del mismo estatus socioeconómico que estaban dispuestas a participar en el estudio. Un total de 97 participantes formados por 67 pacientes con FVV y 30 controles participaron en el estudio. Los resultados revelaron que solo 1 paciente $(1.49 \%)$ era nulípara, $50(74.64 \%)$ y $16(23.88 \%)$ de las pacientes eran multíparas y multíparas grandes, respectivamente. Los resultados de la distribución socioeconómica en el grupo de embarazadas y el control fue en orden de $5>4>3,2>1$. Los niveles de vitamina A en paciente con FVV no mostraron diferencias significativas $(p>0.05)$ en comparación con el control, mientras que los niveles de vitamina $\mathrm{E}$ sí mostraron diferencias significativas $(p<0.05)$. Los resultados de la vitamina A y E con respecto a la edad, clase socioeconómica y paridad mostraron una diferencia significativa $(p<0.05)$ en los pacientes con FVV respecto control, excepto para los de 25-29 y 40-44 años, así como para la clase social 1 y 5 . Por lo tanto, el estudio destaca la necesidad de determinar los valores de referencia de los niveles de vitaminas en la población africana.

PALABRAS CLAVE: fístula genitourinaria, ginecología, embarazo, mortalidad materna, niños, desnutrición, micronutrientes, norte de Nigeria.

\section{REFERENCIAS}

Aboh, J. U., Nwankwo, B. E., Obi, T. C., \& Agu, S. A. Clinical Features Of Patients Diagnosed With Vesico Vaginal Fistula (Vvf) In South East Nigeria. Nat. Sc., 11(12):110-115, 2013.

Akingba, J.B. Outcome of Pregnancy in Short Nigerians. J.Nigerian Med. Assoc., 1: 52-57, 1971.

Babayemi, A. W. \& Olorunpomi, O. T. Model for the Prediction of the Reported Cases of Vesco Vaginal Fistula in Kebbi State. International Journal Mathematics and Statistics Invention., 2(12): 1827, 2012.
Baba, S. B. Birth and sorrow: The psycho-social and medical consequences of Obstetric fistula. Int. J. Sociol. Anthropol., 2 (2): 055-065,2014.

Carl, A.B., Edward, R.A \& David, E.B. Tietz Textbook of Clinical Chemistry and Molecular Health Federation's Proposal for Nutrient Reference Values. 2251-2302, 2006.

Codex, A. The National Gynecological Reproductive Biology. News letter of Japan's Ministry of Health. Tokyo, Japan, 12:347-356, 2000. 
Danso, K. A. Genital tract fistulas. In: EY Kwawukume, EE Emuveyan (eds); Comprehensive gynaecology in the tropics. Accra: Graphic Packaging.,174-181, 2005.

Ekwempu, C.C. Fistulae. In Agboola A. (ed); Textbook of Obstetrics and Gynaecology for Medical Students. Heinemann Pub. Nigeria., 1: 4659, 1988.

Kasongo Project Team. Antenatal Screening for Fetopelvic Dystocias: a Cost- Effectiveness Approach to the Choice of Simple Indicators for Use by Auxiliary Personnel. J. Trop. Med. Hyg., 184:173-183, 1987.

Karshinia, J.A, Otubu J.A.M. Fistula. In: Agboola A. (Ed); Textbook of obstetrics and gynaecology for medical students. Nigeria: Heinemann Educational.,39-51, 2006.

Kelly, J \& Kwast, B.E. Obstetric Vesico-Vaginal Fistulas: Evaluation of Failed Repairs. Int. J. Urogynecol., 4: 271-273, 1993.

Lawson, J.B. Injuries of the urinary tract. In Lawson J. B \& Stewart DB (eds); Obstetrics and Gynaecology in the Tropics and Developing Countries. Arnold, London, 111 - 120, 1967.

Lawson, J. Vesico-Vaginal Fistulae. Postgraduate Doctor. 14: 29-34, 1992.

Mallika, P.E. Maternal height and reproductive performance. J. Obstet. Gynaecol. India., 24:3640, 1974.

Mehmood, A., Alvi, M. S., Rana, S., Raziq, S., Siddiq, L., \& Shah, M. Y. Vesico-Vaginal Fistula: Interposition Flap, a Key to Success. J Ayub Med Coll Abbottabad, 21(3): 29-31, 2009.

Ngoma, J. Prevention of Vesicovaginal Fistula - a literature review and experience from Zambia. [Bachelor's Thesis submitted to Degree programme|Nursing]. Turku University of Applied Sciences, 9-20, 2010.

Odu, B. K. \& Cleland, J. The Psycho-Social consequences of Vesco Vaginal Fistula among Women in Northern Nigeria. Arabian J. of Bus. Manag. Rev. (AJBMR), 1 (8):1-14, 2013.

Okaka, J. C., Akobundu, E. N. T. \& Okaka, A. N. C. Food and Human Nutrition an Integrated Approach. OCJ. Academic Publishers., 135 - 368, 2006.
Okoye, U. O., Emma-Echiegu, N., \& Tanyi, P. L. Living with vesico-vaginal fistula: experiences of women awaiting repairs in Ebonyi State, Nigeria. Tanzan. J. Health. Res., 16(4):1-9, 2014.

Peel, K. R. Premalignant and Malignant Diseases of the Cervix. In Whitfield C.R. (ed); Dewhursts Textbook of Obstetrics and Gynaecology for Postgraduates. (ed 5). W. A Mclndoe, M. R McLean and R.W Jomes Ltd, USA, 456 - 679, 1994.

Rush, D. Nutrition and Maternal Mortality in the Developing World. Am J Clin Nutr., 72(1): 212S 240s, 2000.

Thomson, A.M. Maternal Stature and Reproductive Efficiency. Eugenics Revolution., 51:157-162, 1959.

Umoiyoho, A. J., Inyang-Etoh, E. C., Abah, G. M., Abasiattai, A. M. \& Akaiso, O. E. Quality of life following successful repair of vesicovaginal fistula in Nigeria. Rural Remote Health.,11(3): 1734, 2011.

Uraku, A. J., Onuoha, S. C., Edwin, N., Ezeani, N., Ogbanshi, M. E., Ezeali, C., Nwali, B. U., \& Ominyi, M. C. Nutritional and anti - nutritional quantification assesment of cymbopopgon citratus leaves. J. Pharmacol Pharma., 6: 401-410, 2015.

Waaldijk, K. Technical Report on Vesico-Vaginal Fistula in Nigeria. Int. J. Urogynecol., 4: 273-279, 2003.

\section{Corresponding author:}

Uraku, Anayo. Joseph.

Department of Biochemistry, Ebonyi State

University, Abakaliki, Nigeria

Phone: (+234) 8068073037

E-mail: urakuaj@yahoo.com urakuaju@gmail.com.

Conflict of Interest. No conflict of interest Financial Interest: There is no financial support from any source

Acknowledgements: Authors are grateful to Medical Director of Evangel Hospital, Jos and their entire staff.

Receipt: 14-11-2017

Acceptance: 26-11-2017 